\title{
Hidden Voices and Gothic Undertones: Slavery and Folklore of the American South
}

\author{
Jennifer Dos Reis Dos Santos
}

Aberystwyth University, Wales

\begin{abstract}
African American folklore embodies themes of the Tropical Gothic. It has an air of mystery as it has a deeper meaning underneath the different layers of plot. Folklore of the American South represents the darkness of the slavery period and its implications for African Americans. This article discusses two folklore collections: Uncle Remus, His Songs and His Sayings: The Folk lore of the Old Plantation by Joel Chandler Harris, and From My People: 400 Years of Folklore by Daryl Cumber Dance. Both collections illuminate the ways in which West African oral tradition became a source of empowerment, courage and wisdom for the enslaved African Americans. Folk stories served as a means of silent resistance and preserved the cultural heritage of African Americans.
\end{abstract}

Keywords: Slavery, folklore, American South, American Gothic, Southern Gothic 


\section{Introduction}

$\mathrm{F}$ olklore of the American South is of great value to African Americans as it gives a profound insight into their history and culture. It keeps the memory of experiences during the period of slavery alive. Slaves stolen from West Africa adapted the storytelling practices of their ancestors to cope with and record their experiences in America. Slaves were consciously transmitting their African culture through the West African tradition of storytelling. As such, the dark times of slavery are the main theme of nineteenth century folklore. Likewise, the suffering and displacement of slaves and issues of racism are also strongly represented in the American Gothic genre.

Joel Chandler Harris's folklore collection, Uncle Remus, His Songs and His Sayings: The Folk-lore of the Old Plantation (1882), is a form of cultural heritage. The animal stories became the only way for African Americans to form a voice. A contemporary folklorist, Daryl Cumber Dance, demonstrates how African Americans questioned the theories of their alleged inferiority through her folk tale collection, From My People: 400 Years of African American Folklore (2002). These tales illuminate how the folk tradition places emphasis on what is important to African Americans. Both collections are evidence of how folklore can be used in different ways and how it can express and reflect cultural ideas and morals. The two collections also demonstrate the changes the oral tradition went through when West Africans were enslaved and brought over to America. A Gothic reading of these folk tales will shed light on how this West African tradition was used as a form of catharsis.

The nineteenth century marks the beginning of written African American folklore when the Anglo American journalist, Joel Chandler Harris, recorded the oral stories for the first time. Through his written record Harris allowed his Anglo American readers to delve into the unknown world of African Americans whose culture, wisdom and knowledge had been suppressed since the beginning of slavery in 1619. In order to hold on to their West African traditions, oral storytelling and the ancient West African religion, Voodoo, were practiced in secret, allowing slaves to immerse themselves in their rich cultural heritage while in a country that dehumanized them.

As freedom of speech and expression were denied, the hidden feelings and hopes of the enslaved African Americans are voiced in their folklore. Animal stories, in particular, establish how African Americans gained emotional release from their torments by depicting themselves as victorious creatures. Emotional release was key to mental health and helped them work through daily sorrows during the slavery period. Similarly, 
American Gothic "has given voice to suppressed groups". As Charles Crow states, "the Gothic exposes the repressed, what is hidden, unspoken, deliberately forgotten, in the lives of individuals and of cultures" (Crow, 2009, p.2). This article argues that the folktales recorded by Joel Chandler Harris and Daryl Cumber Dance reveal hidden voices of the enslaved African Americans, while a close reading of the tales demonstrates their Gothic undertones.

\section{Folklore and the American Gothic}

One of the key concerns of American Gothic is race. Morrison's critical work identifies "moments when American literature was complicit in the fabrication of racism" (Morrison, 1990, p.16). The institution of slavery not only formed the basis of Gothic literature but it became a way to perpetuate and enrich white supremacy through literature.

Black slavery enriched the country's creative possibilities. For in that construction of blackness and enslavement could be found not only the not-free but also, with the dramatic polarity created by skin color, the projection of the not-me. (Morrison, 1990, p.38)

In a sense, a Gothic reading of Harris's folklore collection liberates the hidden voices of nineteenth century African Americans. Morrison argues that slavery created an African American self that was not accurate and by applying the same analysis to Harris's folk tales it is possible to uncover the true meaning of those stories.

Slavery in the subtropical American South is at the heart of the American Gothic genre, which often employs tropes of slave trade atrocities and obsessions with power. As Theresa Goddu comments "the Anglo-American Gothic was forged in the crucible of an Atlantic history propelled by the slave trade and the institutions of slavery" (2014, p.71). Elements of the slavery period that have seeped into the Gothic genre include "evil villains and helpless victims, vexed bloodlines and stolen birthrights, brutal punishments and spectacular suffering, cruel tyranny and horrifying terror" (Goddu, 2014, p.72). The animal tales in Joel Chandler Harris' folklore collection, likewise, include these tropes, reflecting the ways in which "the violence, terror, and dispossession of the racialized "other" enabled white subjectivity and liberty" (Goddu, 2014, p.71).

Animal stories often disguise multiple meanings. They offer moral guidance and serve educational purposes, passing on wisdom to younger generations. Children are taught important values and are shown the difference between right and wrong. The symbolism 
of hope played a vital role in these stories as they served as a means to reassure enslaved children and gave a voice to African American aspirations.

For the enslaved, animal stories were seen as a means to escape their mental shackles. They adapted the West African model to fit their needs. Slaves embraced the medium of folklore as it provided solace and courage. It allowed them to express their anger, sorrow and hope without being discovered by the plantocrats. Melville Herskovitz comments that "the reluctance to accept slave status might also have encouraged the slaves to retain what they could of African custom to a greater extent than would otherwise have been the case" (Herskovitz, 1958, p.86). Storytelling was not only used as a form of rebellion against their enslavement but as a means to hold on to their African identity as many cultural tropes of the West African oral tradition survived in African American folktales.

As Mary Berry observes, "West African animal stories served as a prototype of the wellknown Uncle Remus stories" (Berry, 1977, p.504), the most famous African American folk tales and the first to be published. Indeed, the stories published in Harris' folklore collection have multiple elements that can be traced back to West Africa. One of the most significant is the figure of the African hare, Hausa Zomo, who, in the American context, became known as Brer Rabbit. Brer Rabbit became the notorious trickster; while the jackal became celebrated as the American fox. The symbolism attached to Brer Rabbit is significant to the understanding of African American folk stories. The rabbit is associated with "cunning, swiftness, vigilance, guile, and magical powers" (Wernes, 2004, p.339). Using the rabbit to symbolize African Americans is fitting as they used cunning to overcome the institution of slavery. Therefore, the rabbit is the most accurate animal to represent African Americans as a symbol of hope.

At first reading, Brer Rabbit's behaviour appears humorous; yet through a closer analysis of the folk tales, this trickster takes on the dark characteristics of the Gothic. Brer Rabbit is surrounded by mystery as he always manages to escape from precarious situations. The rabbit also demonstrates that he is passionate and strong-willed when he confronts the fox. These elements form the basis of the Gothic reading of Harris's folktales. Usually the setting of Gothic literature is one of decay. This fits with the Uncle Remus stories which take place after the American Civil War; a time when the American South was in a state of ruin and in the process of reconstruction. Most folk stories from the nineteenth century take place in the American Deep South. For African Americans this setting represents the darkness and horror of their ordeal. The American South is the place that robbed them of their identity and humanity. The animals portrayed in the folklore collected by Joel Chandler Harris, mask these dark themes. Although depicted as harmless, a 
deeper meaning lays behind their actions. This is especially the case for Brer Rabbit, whose mischievousness, conveys a mysterious sense of dread. Whereas the African hare served as an element of entertainment, Brer Rabbit was used as a way to criticise society and to represent the enslaved African Americans. Brer Rabbit's behaviour became an inspiration for the enslaved to use their cunning to plan the overthrow of their "owners" and their escape from slavery. Harris comments that in these tales "it is not virtue that triumphs, but helplessness, it is not malice, but mischievousness" (Crane, 1969, p.159).

\section{Brer Rabbit as the trickster character and a symbol of freedom}

The characteristics of animal folklore are "themes that were the undergirding of folk rhymes, narratives, jokes, and riddles - such as the quest for freedom, the nature of evil, and the powerful versus the powerless" (Harris, 1882, p.2). These themes underlie the life of African Americans during the nineteenth century. The quest for freedom and the constant feeling of powerlessness mirrors the African American struggle before the Emancipation Proclamation of 1863. Incorporating these themes in their folk stories was of utmost importance as folklore was the only means to express their values and wisdom.

African American folklore shows cultural beliefs and traditions which constitute the essence of oral storytelling. James Miller McKim comments that folklore "tell[s] the whole story of these people's life and character. There is no need after hearing them, to inquire into the history of the slave's treatment" (McKim, 1969, p.59). Indeed, the stories not only reflect the lives of the enslaved, but the preoccupations of African Americans.

African American folk tales depict how smaller creatures always outsmart the larger animals. Kathleen Light comments that "what Harris saw in the Brer Rabbit stories was a type of compensatory fantasy which portrayed the triumph of the black man over the white society that had enslaved him" (Light, 1975, p.92). Arguably, folk stories can be seen as a response to the experience of slavery. Depicting the smaller creatures as the ones overcoming the larger and stronger animals shows that African Americans believed in a different power structure, where a supposedly helpless creature is capable of overpowering their enemy. Harris comments that it makes sense for African Americans to choose one of the weakest animals to represent them and their entrapment:

It seems to me to be to a certain extent allegorical, albeit such an interpretation may be unreasonable. At least it is a fable thoroughly characteristic of the negro; and it needs no scientific investigation to show 
why he selects as his hero the weakest and most harmless of animals. (Harris, 1883, p.9)

On closer examination it could be argued that the selection of 'the weakest and most harmless of animals' served to demonstrate that African American slaves were not to be feared. Yet, simultaneously, the power given to the vulnerable in the stories gives them a rather uncanny character. One is made to believe that they are not what they seem to be; Brer Rabbit is not only a rabbit but also a rebel.

Animal folk tales were also used to instil courage and hope in the younger generations. It was important for young people to carry the anticipation of freedom to adulthood, as they could possibly be the ones fighting for emancipation. Mary Berry observes that the folk tales taught young African Americans how to mask their true feelings, to resist anger and to learn patience:

Among the slaves the folktale was also a means of training young blacks to cope with bondage. By modelling their behaviour on that of the rabbit or tortoise, the slaves learned to use their cunning to overcome the strength of the master, to hide their anger behind a mask of humility, to laugh in the face of adversity, to retain hope in spite of almost insuperable odds [...] (Berry, 1977, p.504)

The animals taught them that masking their feelings would eventually lead to victory. Brer Rabbit, furthermore, demonstrates an unconscious wish for breaking the rules, and he gets away with it. Susan Schramm comments that "the primary goal of the trickster is social nonconformity by redefinition of norms for life and existence in mainstream American society" $(2000$, p.20). As a character who refuses to follow the norms of behaviour, the rabbit creates and follows his own rules. Psychoanalyst Sigmund Freud once said that "the dream is the liberation of the spirit from the pressure of external nature, a detachment of the soul from the fetters of matter" (1997, p.40). The rabbit can be interpreted as the expression of African Americans' dream for liberation from the rules imposed on them in the United States. This character depicts the conscious hope to live in a world where they are not perceived as inferior human beings.

African Americans had no idea what the future held for them; freedom, or death as a slave. This fear and anxiety - and its overcoming- is reflected in the behaviour of Brer Rabbit. Susan Schramm argues that 
The trickster figure in African American culture evolved through the slave narrative, which describes this archetype as a free spirit whose behavior is complex and contradictory. This figure is often shown pursuing wisdom, cunning, or power and attempting to redefine the social order. (Jeffries, 2000, p.20)

As the trickster character is shown to reformulate culture, it could be argued that he depicts the African American's dream for emancipation. Freud comments that "what is common in all [...] dreams is obvious. They completely satisfy wishes excited during the day, which remain unrealized. They are simply and undisguisedly realizations of wishes" (Freud, 1997, p.28). Incorporating their wish for freedom in a fictional character, African Americans were freeing themselves for the brief period of story telling. In Freudian terms; the slaves' unrealized wish to overthrow and trick the Anglo American masters was embodied in the trickster character.

After overcoming physical slavery, African Americans had to battle against mental slavery. Mental slavery was the entrapment of their thoughts as they were prevented from expressing themselves freely and had lived under the forces of discrimination and stereotyping. Kinnard asserts that "a laughing, singing, fiddling, dancing negro is almost invariably a faithful servant" (1969 p.32). This type of stereotyping not only gave African Americans a fixed role, but it diminished their worth. Even after emancipation, they had to stick to the 'faithful servant' stereotype to guarantee their survival and integration into Anglo American society.

Born in 1848 Harris was an Anglo American journalist who grew up in a slave owning location listening to the tales told by slaves. This enabled him to become familiar with the lore and dialect of the slaves. Harris, sitting "with a group of black workers at a railroad station near Atlanta one summer night in 1882, [...] overcame his formidable shyness and swapped folktales with his companions, tales he would never share orally with white people" (Mixon, 1990, p.459). This not only shows camaraderie between Harris and African Americans, but the practice of swapping folk tales with African Americans enabled Harris to get a more accurate and authentic version of the tales.

Although it could be argued that Harris, through this method, verified his folk stories before publishing them, it is noted that "it was a comparatively easy matter for [him] to take the stories away in his memory, since many of them gave point to a large collection of notes and unrelated fragments already in his possession" (Harris, 1883, p.3). Thus, he would often write the stories from recall or from mere outlines furnished to him (Mixon, 1990, 
p.467). Nevertheless, Harris' folklore is authentic in the sense that it represents the original stories told amongst the African American community.

In writing down the folk tales, Harris becomes a ventriloquist. He is impersonating the African American voice and character and is therefore not only representing African Americans but making their culture and stories accessible to Anglo American readers and in the process, presumably adapting aspects to suit his reading audience. In this respect, Brer Rabbit's less desirable traits, including his inclination to thwart society's rules of conduct, are especially interesting as they are what made him so appealing to his Anglo American reading, and African American telling and listening, audiences. Hope Wernes comments that "Brer Rabbit often behaves precipitously and rashly and his less desirable traits often land him in deep trouble" (Wernes, 2004, p.340). During the nineteenth century, the slave codes ensured that these character traits were controlled. The codes were "seen as precautionary measures designed to forestall the likelihood of slave insurrections, petty thievery, miscegenation, escapes, and countless other infractions associated with the frustrations of an oppressed people" (Thompson, 1993, p.324). The protagonist, Uncle Remus, comments that people with troublesome characters never succeed in their endeavours. Undesirable traits would have made life harder for the newly emancipated African Americans. He says that "folks w'at's allers pesterin' people, en bodderin' 'longer dat w'at ain't dern, don't never come ter no good eend" (Harris, 1882, p.63). It is better to follow the rules and be obedient as compliance was still a factor that ensured survival. Compliance became the new norm for African Americans. Thus, the telling of folk tales was not only a means for release, but their subversive storylines, offered a different life story for African Americans.

The main protagonist of Harris' collection is Uncle Remus. In portraying Uncle Remus as an African American who "knows his place" Harris is communicating to Anglo American readers of the period, that there is nothing to fear. He is conveying the message that African Americans are harmless, and they just want to keep embracing their roles as servants. Harris was collecting folk stories during a time when Anglo Americans were anxious about African American retaliation for the huge injustices perpetrated against them. Former slave Mattie Aldridge explains that African Americans "was glad when freedom declared. They said [Anglo Americans] was hard on 'em. Whoop 'em" (Born in Slavery n.d., p.22). Understandably, many African Americans, like Mattie Aldridge, expressed resentment towards Anglo American society, as it was responsible for their mistreatment and dehumanization. This period become dark and dangerous, and it is looked upon with resentment. Literary works of the American South reproduced that sense of "gothic conflict between defenseless victims and abusive tyrants within a 
racialized framework, endeavoring to capture American anxieties concerning racial uprisings as it deconstructs racial patterns through the exploration of a space between blackness and whiteness" (Edwards, 2002, p.38). At this time of foreboding, the folk tales became a strategy to ease Anglo American anxiety.

The portrayal of Uncle Remus is problematic for contemporary readers as the character appears modelled on racist stereotypes of nineteenth century African Americans. Alice Walker comments, "I believe that the worst part of being in an oppressed culture is that the oppressive culture can so easily make us feel ashamed of ourselves, of our sayings, our doings, and our ways" (Walker, 1987, p.32). However, for Anglo American readers at the time of publication, Uncle Remus was seen as a compliant representation of African Americans. It has been noted by Mixon that "Harris knew that progress in race relations depended primarily upon improvement in white attitudes" (Mixon, 1990, p.457). Thus, it could be argued that Harris tried to alleviate racial tensions after the American Civil War through the publication of the folk tales, including the portrayal of Uncle Remus as an African American who remains content serving Anglo Americans even after the Emancipation Proclamation. The legacy of this portrayal is complex. As Toni Morrison comments, "[Her] early assumptions as a reader were that black people signified little or nothing in the imagination of white American writers" (Morrison, 1990, p.15). This is true on two points. Firstly, Harris appropriated the stories from African Americans and published them under his name. He claimed the stories that slaves brought over from Africa and stole - as well as preserved - part of their heritage. Secondly, the stories portray African Americans as subservient. It is this second point that requires further analysis for its hidden voices and gothic undertones.

\section{Joel Chandler Harris' folklore collection as a form of cultural therapy.}

One of the short stories in Harris' collection entitled 'How Mr. Rabbit Was Too Sharp for Mr. Fox', is the continuation of the well-known folk tale 'The Wonderful Tar Baby Story'. This story is a good example of how Brer Rabbit always manages to outsmart Brer Fox. At the beginning of the tale Uncle Remus says that "wen Brer Fox fine Brer Rabbit mixt up wid de Tar-Baby, he feel mighty good, en he roll on de groun' en laff' (Harris, 1882, p.29). The fox taking pleasure in trapping the rabbit can be linked to the imagery of Anglo Americans trapping African Americans. For over two centuries, the institution of slavery enabled Anglo Americans to have power over their human chattel. The portrayals of Brer Fox, who represents Anglo Americans, as the creature that constantly tries to capture and hurt Brer Rabbit, mirrors the social relations from the period of slavery. 
The Fox further comments "well, I speck I got you dis time, Brer Rabbit, sezee, maybe I ain't, but I speck I is. You been runnin' roun' here sassin' atter me a mighty long time [...]" (Harris, 1882, p.29). This statement can be interpreted as the fox representing a slave catcher who chases after runaway slaves. In some cases, African Americans would manage to trick slave catchers through various means such as the Underground Railroad. ${ }^{1}$ Saying that the Rabbit "come ter b'leeve [himself] de boss er de whole gang. En den [he] allers some'rs whar [he] got no bizness [...]" (Harris, 1882, p.30) can be understood as Brer Rabbit being the one causing trouble. He is a nuisance. This imagery may be interpreted as the belief that African Americans were a danger to Anglo American society after emancipation.

Many Anglo Americans expressed anxiety over the former slaves' newly gained freedom and mobility. Joe Feagin points out that a separatist movement prevented emancipated African Americans from being included in the Anglo American community. He states that "whites who supported separatism seemed to be fearful of the effects of emancipation on the 'purity' of the American racial stock and on the quality of American civilization" (Feagin, 1971, p.168). Crow comments, "the rebellious slave is a powerful figure, one of the most potent, indeed, in American culture of the time, because he is based on a fear understood by both black and white Americans" (Crow, 2009, p.35). This fear can be linked to the Gothic. Slaves wore a mask of contentment and never voiced their true thoughts and feelings. The Fox further asserts "en dar you is, en dar you'll stay twel I fixes up a bresh-pile and fires her up, kaze l'm gwineter bobbycue you dis day" (Harris, 1882, p.30). The Fox wanting to burn the rabbit alive can be interpreted as a reference to the Ku Klux Klan and its night-time activities that involved lynchings and the destruction of African American property. The wish to cause agony adds to the horror that African Americans had to endure.

A shift from social relations to humour can also be discovered in Harris' folklore collection. In 'Mr. Rabbit Grossly Deceives Mr. Fox' evidence of African American humour can be found when Brer Rabbit says that "Brer Fox wuz my daddy's ridin-hoss fer thirty-year; maybe mo', but thirty year dat I knows un [...]" (Harris, 1882, p.36). African Americans had been forced into hard physical labour since the arrival of the first slave ship in Jamestown, Virginia in 1619. To depict the Fox as the one who carries Brer Rabbit's father shows that the fables reverse the racial roles of the 19th century. Brer Rabbit takes control, and with this power, demonstrates that the Fox is continually confronted with

\footnotetext{
${ }^{1}$ The Underground Railroad is the name given to a network of secret routes and safe houses established by AfricanAmerican Slaves and aided by allies and abolitionists. It was used by slaves to escape to free states in the north.
} 
powerlessness. Raymond Hedin states that "in the post-reconstruction era, when whites were doing everything they could to reassert their control over blacks, Harris reminds his readers that there is at least one area, the world of black folk tales, where whites have no control whatever" (Hedin, 1982, p.85). Indeed, the community stories depict Brer Rabbit as the one who is constantly in control. The Fox, on the other hand, is always defeated by Brer Rabbit's tricks and cunning.

This story shows the Fox as a fool who is constantly ridiculed as he unwisely accommodates the Rabbit's needs. Brer Fox agreed to "ride Brer Rabbit mos' up ter Miss Meadows's, en den he could git down en walk de balance er de way" (Harris, 1882, p.37). In this regard the tale is a form of cultural therapy. As Crow states, "the Gothic may be seen as cathartic, a process of confronting fears and healing the injuries inflicted on individuals and societies by traumatic stress, change and rigid authority" (Crow, 2009, p.3). Indeed, reversing racial roles through their oral stories is a means to make a farce of their bondage. It also allows African Americans to confront their own feelings towards the institution of slavery. The tale shows that even though Brer Rabbit seems weaker than Brer Fox, he still manages to make Brer Fox do his bidding.

Joel Chandler Harris collected folklore during a time when African Americans were going through massive life changing events. Harris' main aim in recording the folk stories was to make sure that the tales would not be lost. His folklore collection was published in 1880 and by that time African Americans were emancipated. Harris wanted to preserve the folk tales as he anticipated a change in African American behaviour. Indeed, after emancipation, some African Americans denounced their folklore and African heritage and saw it as a negative feature of their identity and culture: "Overcoming racist oppression and abject poverty through education was much more important to blacks than questions of culture" (Anderson, 2005, p.25). African American linguistic and cultural distinctiveness went through a change as they adopted Anglo American mannerisms. Alice Waker states, "even our folklore has been ridiculed and tampered with. And this is very serious, because folklore is at the heart of self-expression and therefore at the heart of self-acceptance" (Walker, 1987, p.32).

\section{The power of satire in Etiological folklore}

In 2002 the folklore collection From My People: 400 Years of African American Folklore was published by Daryl Cumber Dance. This collection celebrates and shares the cultural heritage found in African American oral storytelling. Dance states that her "goal in collection is to acquaint readers with the broad range of folk expressions, from the 
creations of enslaved Africans to contemporary forms". And continues that "efforts to include contemporary materials have reinforced the need for new definitions of folklore in a twenty-first-century world" (Dance, 2002, p.xxxviii). She comments that "if we want to know what things mean to many Black people, our best source is unquestionably the African American folk tradition" (Dance, 2002, p.xxxv). Indeed, African American folklore transmits African American identity which gives readers the opportunity to learn more about certain meanings and purposes. Harris and Dance created their volumes in different time periods and therefore their folklore collections have a different purpose. Joel Chandler Harris' collection was published in 1882 as African Americans were newly emancipated. Daryl Cumber Dance, on the other hand, puts emphasis on how folklore was also embraced during the twentieth and into the twenty-first century. Her collection demonstrates how folklore has evolved and merged with changing African American culture. The folk tales in her collection also address the question of how things came to be as they are. These etiological fables are satirical and explore how African Americans grappled with the entrenched idea of their alleged inferiority. Here, the Gothic becomes a means to express the psyche of African Americans.

The satirical element embedded in these folk tales reveals the ways in which African Americans challenged and discredited the theories of their inferiority. Irony became a means of resistance against Anglo Americans - and a way to ridicule them. The folk tales highlight the stereotypes that were attributed to African Americans and simultaneously satirize Anglo American perceptions of the African American as the 'Other'. This can be seen in tales such as 'Why the Black Man's Hair is Nappy' and 'Why de Whites Have Everything'. As Dance articulates, African American etiological tales are "myths that tend to focus on the world as it evolved and to frequently portray the role of God in explaining" their inferior status (Dance, 2002, p.53). They illustrate "why [African Americans] ain't got nothin' today" and why "white people got it all" (Dance, 2002, p.10). In other words, this type of folklore serves as a way of explaining the underprivileged situation of many African Americans. It is a protest tale that contests the way African Americans were perceived as inferior human beings by Anglo Americans during the nineteenth and twentieth centuries.

Richard Dorson states that "the protest tale characteristically makes use of irony and inversion, rather than overt social criticism, by having colored folk accept the white man's code and extend it to the point of absurdity" (Dorson, 1972, p.92). The tales show that African Americans do not believe in the idea of an inferior or superior "race" but that they believe in equality. The use of irony or satire in these folk tales demonstrates that African Americans do not believe that Anglo Americans are entitled to define humans' status. 
According to Dance, the tales articulate how God is the only one allowed to pass judgment, as he is the one making the world.

God was making the worl' and He called the people, you know, de white people to get a bag and de colored people to get a bag. De colored people went to get the little and the white people get the big bag; and the heavy bag [there] was money in it, and the light bag ain't have nothin' in it. And they say dat's why us ain't got nothin' today; white got it all. (Dance, 2002, p.10)

In this tale irony is employed to demonstrate that African American poverty is due to them picking the light bag during creation. The fable thus provides an explanation for the anomaly of slavery and its aftermath. As Dance comments "these tales purport to be myths explaining the role of God in creating the racial situation that exists in America" (Dance, 2002, p.3).

This type of folk tale characteristically begins with the creation myth. To trace back the African Americans' alleged inferiority one has to go back to the beginning of everything. The creation myth usually depicts the African American as the one given the least attention by God.

When the Creator made man, He was making the white man first, and all of the scrap pieces, the ends of the fingernails and the toes and the backsides, and what have you, He said, 'Well, I don't know what I'm gon' do with all of these ends. l'll throw them over here in the corner, and when I get time, I'll decide what to do with them". (Gates, 2018, p.388)

Out of these scraps "something popped out of the corner [and says] "Lawd, here me!"' (Gates, 2018, p.388). This creation tale shows how the African American man brings himself into existence from scraps and leftovers of previous creations. The tale ends by saying that this is "why the nigger is so messed up. He could not wait until the Lord fixed him right. He had to make himself" (Gates, 2018, p.388). The title of this tale, 'Why the Nigger is so Messed Up', mocks the notion of racial inferiority. African Americans are not 'messed up' because the man made out of scraps appears to be complete. God even says "since you so smart, now, you stay like that" (Gates, 2018, p.388). The African American had the intelligence to create himself out of leftovers whereas the Anglo American had to be created by God. In a sense, African Americans demonstrate that they have the intelligence to not only make themselves, but to survive the trial of life. This tale 
illustrates a concept of agency that shows that African Americans are independent and can make their own decisions.

Etiological tales can also be seen as a satirical commentary on White society and its beliefs in supremacy. "[C]ertainly it would not be the first time Black appropriated white stereotyping of them and used those same stereotypes for a counterattack" (Dance, 1977, p.61). It could be argued that the target of those tales is the racist American system, which not only segregates African Americans but all other ethnicities. Charles Knight writes that etiology "becomes problematic as a genre because of the tensions between the selfconsciously formal character of its medium and particular reality of its attack" (Knight, 1992, p.22). Etiology not only reflects the anger and resentment towards the Anglo American community but the language and imagery in the tales creates a racial barrier/tension between both communities. The tales can be interpreted as a form of literary war to fight back against those who seek to undermine and destroy the African American community. These tales provide a literary style with which to break the legacies of slavery and confront the Anglo American community for African Americans' past mistreatment, their murders, and their abductions from native countries.

Folklore is also a way for African Americans to spiritually connect with Africa as West African slaves brought the tradition of storytelling to America. This tradition became part of the African America community. The transatlantic slave trade not only ripped slaves from their native lands but it brought a new tropical culture to the Americas. Keith Cartwright comments, "although the Deep South's subtropical landscape, substantial black populations, and colonial immigrations of people and institutions from the West Indies ensured its position as a Creole matrix, too few Americans have recognized the vigour of the Afro-Creole foundational presence" (Cartwright, 2004, p.7).

\section{Conclusion}

An unidentified author comments in an 1856 article that "inferior to the white race in reason and intellect, [African Americans] have more imagination, more lively feelings and a more expressive manner" (Songs of the Blacks, 1969, p.52). Intellect and imagination are two of the primary functions of the human mind, but folk tales also have a hidden reason and intellect, and African Americans have shown their cunning imagination through their folk tales. African Americans should embrace the study of folklore as the tales' hidden meanings provide creative inspiration as well as complex historical understandings. Folklore tells the history of a people banned from reading and writing during the period of slavery. Its value is therefore immeasurable, as the tales are records 
of African American history and culture. Folklore is enhanced by Gothic elements, which help convey the African American message of despair in the nineteenth century. Folklore of the American South is "a dark and abiding presence, there for the literary imagination as both a visible and an invisible mediating force" (Morrison, 1990, p.46). The darkness of these folk stories are imbued with Gothic tropes, always leading to a remembrance of slavery and its implications for African American culture.

As a ventriloquist, Harris adopted, impersonated and adapted the African American voice and character, which enabled Anglo Americans to read the folklore of African Americans for the first time. Harris was therefore not only representing African Americans but also making their culture accessible to the whites. However, the authenticity of the recorded folk tales needs to be put under question as Harris was writing specifically for an Anglo reading audience. Daryl Cumber Dance sees the importance of cultural heritage in the folklore of her ancestors. The past is important in understanding the future and her folklore collection commemorates the consciousness of African Americans. Her collection not only documents how the enslaved have spiritually survived, but demonstrates the importance of folklore as an expressive tool.

African American folklore is a "cultural heritage which served as the foundation for the development of African American culture [and it] continues to be the traditional rich source of black vernacular creativity in the United States" (Roberts, 1993, p.161). These stories keep the old African traditions alive as they are retold from generation to generation and they are a means of tracing back one's cultural heritage. Folk stories preserve and disseminate African American identity as other cultures hear and retell those stories. The folk tradition can give the individual a sense of identity as they see themselves in a certain story or character. African Americans learn about their ancestor's struggles through the medium of folklore. 


\section{References}

Anderson, J. E. (2005). Conjure in African American Society. Baton Rouge, LA: Louisiana State University Press.

Berry, M. F. (1977). Africa, Slavery, \& the Roots of Contemporary Black Culture. The Massachusetts Review, 501-516.

Born in Slavery: Slave Narratives from the Fedreral Writer's Project, 1936 to 1938. (n.d.). Library of Congress. https://www.loc.gov/collections/slave-narratives-from-the-federal-writersproject-1936-to-1938

Crane, T. (1969). Plantation Folk-lore. In B. Jackson, The Negro and His Folklore in Nineteenth Century Periodicals. Austin, TX: University of Texas Press.

Cartwright, K. (2004). Reading Africa into American Literature: Epics, Fables, and Gothic Tales. Lexington, KY: University Press of Kentucky.

Crow, C. L. (2009). History of the Gothic: American Gothic. Wiltshire, UK: University of Wales Press.

Dance, D. (1977). In the Beginning: A New View of Black American Etiological Tales. Southern Folklore Quarterly, 40, 53-64.

Dance, D. C. (2002). From My People: 400 Years of African American Folklore. London, UK: W.W. Norton \& Company Ltd.

Dorson, R. M. (1972). Folklore: Selected Essays. Bloomington, IN: Indiana University Press.

Edwards, J. D. (2002). Gothic Passages: Racial Ambiguity and the American Gothic. lowa City, IA: University of lowa Press.

Feagin, J. R. (1971). White Separatists and Black Separatists: A Comparative Analysis. Social Problems, 167-180.

Freud, S. (1997). The Interpretation of Dreams. London, UK: Wordsworth Editions.

Gates, H. L. (2018). The Annotated African American Folktales. Canada: W.W. Norton \& Company Ltd.

Gemes, K. (2009). Freud and Nietzsche on Sublimation. Journal of Nietzsche Studies, 38, 38-59. DOI: $10.1353 /$ nie. 0.0048

Goddu, T. A. (2014). The African American Slave Narrative and the Gothic. In C. L. Crow, A Companion to American Gothic (pp. 71-83). London, UK: John Wiley \& Sons Ltd.

Harris, J. C. (1882). Uncle Remus, His Songs and His Sayings: The Folk-lore of the Old Plantation. New York, NY: D. Appleton and Company.

Harris, J. C. (1883). Nights With Uncle Remus. London, UK: George Routledge and Sons. Harris, T. (1991). Fiction and Folklore: The Novels of Toni Morrison. Knoxville,TN: The University of Tennessee Press.

Hedin, R. (1982). Uncle Remus: Puttin' on Ole Massa's Son. The Southern Literary Journal , 15 (1), 83-90.

Herskovitz, M. (1958). The Myth of the Negro Past. Boston, MA: Beacon Press.

Kinnard, J. Jr. (1969). Who Are Our National Poets? In B. Jackson, The Negro and His Folklore in Nineteenth Century Periodicals. Austin, TX: University of Texas Press.

Knight, C. A. (1992). Satire, Speech and Genre. Comparative Literature, 22-41.

Light, K. (1975). Uncle Remus and the Folkorists. Southern Literary Journal, 7, 88-104.

McKim, J. M. (1969). Negro Songs. In W. B. Jackson, The Negro and His Folklore in Nineteenth Century Periodicals. Texas, TX: University of Texas Press. 


\section{éropić}

Minnick, L. C. (2004). Dialect and Dichotomy: Literary Representations of African American Speech. Tuscaloosa, AL: University of Alabama Press.

Mixon, W. (1990). The Ultimate Irrelevance of Race: Joel Chandler Harris and Uncle Remus in Their Time. The Journal of Southern History, 56 (3), 457-480. DOI: 10.2307/2210286

Morrison, T. (1990). Playing in the Dark: Whiteness and the Literary Imagination. New York, NY: Vintage Books.

Roberts, J. W. (1993). African American Diversity and the Study of Folklore. Western Folklore, 52 (2/4), 151-171.

Snyder, T. L. (2010). Suicide, Slavery, and Memory in North America. The Journal of American History, 97 (1), 39-62.

Schramm, R. J. (2000). African American Trickster Representations in the Work of Romare Bearden. Art Education, 19-24.

Songs of the Blacks. (1969). In W. B. Jackson, The Negro and His Folklore in Nineteenth-Century Periodicals. Texas, TX: University of Texas Press.

Thompson, J. C. (1993). Toward a More Humane Oppression: Florida's Slave Codes, 18211861. The Florida Historical Quarterly, 324-338.

Walker, A. (1987). Living By the Word: Selected Writings 1973-1987. London, UK: The Women's Press Limited.

Wernes, H. B. (2004). The Continuum Encyclopedia of Animal Symbolism. London, UK: The Continuum International Publishing Group Inc. 